\title{
Introduction:
}

Versailles and the Broadening of 'Peace Through Law'

\author{
Michel Erpelding*
}

On 9 May 1919, a little more than forty-eight hours after the Allies had handed over the text of the Versailles Treaty to the representatives of Germany, a small ceremonial dinner was held at the Hôtel Bedford, in the fashionable $8^{\text {th }}$ arrondissement of Paris. As one American attendee later wrote to his wife, it was a high-brow affair. The guest list included a grandnephew of Napoleon I, Prince Roland-Napoléon Bonaparte, and Albert I, Prince of Monaco. However, like their host, the British barrister and academic Sir Thomas Barclay, most of the twenty or so diners were highly regarded authorities on international law. They were also members of the Institut de Droit International (IDI), which, a few hours earlier, had concluded an extraordinary two-day session at the Ceremonial Hall of the Paris Law Faculty. All were gathered to honour the man whose ideas were profoundly changing the way people thought about international relations and international law: the President of the United States of America, Woodrow Wilson. ${ }^{1}$

The IDI had not convened since its Oxford session in August 1913-its subsequent session, meant to take place in Munich in September of the following year, had been cancelled after the summer of 1914 had ended in mobilization and war. ${ }^{2}$ Founded in 1873 as a reaction to the Franco-Prussian war of 1870-1871, the IDI had vowed to 'promote the progress of international law'. By declaring that they would '[strive] to formulate the general principles of the subject, in such a way as to correspond to the legal conscience of the civilized world', its members had openly challenged the monopoly of governments over international law. ${ }^{3}$ The idea that international disputes might be better resolved by legal experts rather than governements or diplomats had also been gaining ground among a somewhat

* Senior Research Fellow, Max Planck Institute Luxembourg for Procedural Law.

1 'Avant-propos' (1919) 27 Annuaire IDI V-XII.

2 ibid.

3 Martti Koskenniemi, The Gentle Civilizer of Nations: The Rise and Fall of International Law, 1870-1960 (CUP 2001) 47. 
broader public. 'Realist' pacifist associations, such as the British International Arbitration League, founded in 1870, or the French Association de la Paix par le Droit ('Peace through Law Association'), established in 1887, were advocating compulsory international arbitration as an alternative to classic diplomacy. As an exclusive academic society, the IDI had always steered clear of pacifism. However, it had actively supported and contributed to the development of international arbitration as a means to avoid war. ${ }^{4}$

Its efforts, and those of other groups of international lawyers, such as the American Society of International Law (ASIL), created in 1906, had had a particular resonance with decision-makers in the Americas, particularly in the United States. That very same year, Theodore Roosevelt had become the first statesman to be awarded the Nobel Peace Prize, both for his having negotiated peace between Russia and Japan in 1905 and for having resorted to arbitration in a dispute with Mexico. In 1912, Roosevelt's former Secretary of State Elihu Root-who, like almost all Secretaries of State of that period, was a member of the ASIL and, also, an associate member of the IDI-had also been awarded the Nobel Peace Prize for his pro-arbitration policies. Roosevelt's successor, the lawyer-and ASIL memberWilliam Howard Taft, was an even stronger proponent of international arbitration. On the eve of the First World War, it was therefore a widelyshared belief among international lawyers that their impartial technical expertise would eventually replace diplomacy as the main instrument of international dispute settlement. The Peace Palace, inaugurated at The Hague in August 1913 as the seat of the Permanent Court of Arbitration, seemed to embody the hope for a world in which a small community of international lawyers would prevent sovereign nations from going to war against each other. ${ }^{5}$

By 28 July 1914, when Austria-Hungary declared war on Serbia, that hope had vanished. International law, however, had not. Over the following years, the Allies had consistently claimed the international-legal high ground, while the Germany had tried-although not very successfully-to reciprocate in kind. On the Allied side, the 'war to end all wars' had quickly become a 'war in defence of international law.' The Allied claim to estab-

4 Charles De Visscher, 'La contribution de l'Institut de droit international au développement du droit international' in Institut de droit international (ed), Livre $d u$ Centenaire 1873-1973: Évolution et perspectives du droit international (S Karger 1973) 128, 144-145.

5 Mark Mazower, Governing the World: The History of an Idea (Penguin 2013) 81-93, 120. 
lish a stable postwar order based on international law had raised high hopes among the peoples of Europe and beyond. ${ }^{6}$ This claim had become somewhat more tangible when the United States had eventually joined the fight against the Central Powers in April 1917. Before entering the war, Woodrow Wilson had outlined, based on earlier proposals, a 'peace without victory' backed by a universal 'League for Peace.7 In January 1918, he had re-affirmed this commitment as part of his 'Fourteen Points.' After arbitration alone had proved insufficient to prevent war, the idea of creating an international body that would effectively guarantee world peace had become a central element for proponents of 'peace through law.' In the United States, William Howard Taft and Elihu Root had been among the founders of the League to Enforce Peace in 1915. In France, the Association de la Paix par le Droit had campaigned for it in 1916-1917. After the Allied victory against Germany in November 1918, Wilson had made sure to put it at the top of the agenda of the Paris Peace Conference. After some initial misgivings, the other Allied Powers eventually obliged, with the British taking an especially proactive role in the drafting of what would become known as the Covenant of the League of Nations. ${ }^{9}$

The Covenant and its 26 Articles stood out as the most important common feature of the post-war settlement reached at the Paris Peace Conference. Its pre-eminence was materialized by its inclusion, as Part I, in all the peace treaties negotiated between the Allied and Associated Powers and the Central Powers, ie the Treaties of Versailles (Germany), ${ }^{10}$ Saint-Germain (Austria), ${ }^{11}$ Neuilly (Bulgaria), ${ }^{12}$ Trianon (Hungary), ${ }^{13}$ and Sèvres (Ottoman Empire). ${ }^{14}$ The creation of the first permanent international or-

6 Isabel V Hull, A Scrap of Paper: Breaking and Making International Law during the Great War (Cornell University Press 2014) 2-8.

7 Wilson to Senate (22 January 1917) 40 The Papers of Woodrow Wilson 533-537.

8 Wilson to Congress (8 January 1918) 45 The Papers of Woodrow Wilson 534-539.

9 Florian Couveinhes-Matsumoto, 'Les travaux préparatoires' in Robert Kolb (ed) Commentaire sur le Pacte de la Société des Nations (Bruylant 2015) 7, 11-52.

10 Treaty of Peace between the Allied and Associated Powers and Germany (signed 28 June 1919, entered into force 10 January 1920) 225 CTS 188.

11 Treaty of Peace between the Allied and Associated Powers and Austria (signed 10 September 1919, entered into force 8 November 1921) 225 CTS 482.

12 Treaty of Peace between the Allied and Associated Powers and Bulgaria, and Protocol (signed 27 November 1919, entered in force 9 August 1920) 226 CTS 332.

13 Treaty of Peace between the Allied and Associated Powers and Hungary (signed 4 June 1920, registered 24 August 1921) 6 LNTS 187.

14 Treaty of Peace between the Allied and Associated Powers and Turkey (signed 10 August 1920) 28 LNTS 225. 
ganization entrusted with "[promoting] international co-operation and [achieving] international peace and security ... by the firm establishment of the understandings of international law as the actual rule of conduct among Governments' had also raised important expectations among international lawyers. These expectations had been palpable during the IDI's extraordinary two-day session in Paris on 8-9 May 1919. In his opening statement, Sir Thomas Barclay had expressed the hope that the Versailles Peace Treaty would make international law-and its professionals-even more relevant than before the war:

To deride international law, the Hague Conventions, and the peaceful means [of dispute settlement] because the most terrible war the world has ever known has taken place despite them is just as reasonable as deriding engineers, architects, and all construction work because an earthquake has destroyed some of humanity's finest creations.

Wars are explosions of national wrath, and as long as the tumult is ongoing, nations are not more reasonable than individuals in midst of a violent argument.

Today, the tumult subsides and men are returning to their normal state of mind. Moreover, the reaction to that tumult has been the creation of the League of Nations, providing international law with the binding force that it lacked. ${ }^{15}$

It seems fair to assume that Barclay's reception at the Hôtel Bedford in honour of Woodrow Wilson was not merely intended as a way of paying private homage to an old acquaintance of his. Inviting the main instigator of the League Covenant to a reception mostly attended by scholars and practitioners of international law was likely to be interpreted as a collective celebration of international law and its professionals. Whatever Barclay's intentions had been, Wilson made clear that he was there to celebrate the

15 'Séance d'ouverture du 8 mai 1919' (1919) 27 Annuaire IDI 295-296. Original French: 'Railler le droit international, les conventions de La Haye, les méthodes pacifiques, parce que la plus terrible guerre que le monde ait jamais vue a éclaté malgré eux, est aussi raisonnable que de railler les ingénieurs, les architectes et la science de la construction en général, parce qu'un tremblement de terre a détruit une partie de la plus belle auvre de l'bomme. Les guerres sont des explosions de colère nationale et, tant que dure le tumulte, les nations ne sont pas plus raisonnables que ne le sont les individus au milieu d'une violent dispute. Le tumulte s'épuise et les hommes reviennent à un état d'esprit normal, et déjà le jeu de la réaction produit dans la création d'une Société des $\mathrm{Na}$ tions ce qui manquait pour donner au droit international la force obligatoire qui lui manquait.'. 
former rather than the latter. He agreed with Barclay that the war had only strengthened international law:

I thought it a privilege to come here tonight, because your studies were devoted to one of the things which will be of most consequence to men in the future, the intelligent development of international law. In one sense this great unprecedented war was fought to give validity to international law, to prove that it had a reality which no nation could afford to disregard; that, while it did not have the ordinary sanctions, while there was no international authority as yet to enforce it, it nevertheless had something behind it which was greater than that-the moral rectitude of mankind. If we can now give to international law the kind of vitality which it can have only if it is a real expression of our moral judgments, we shall have completed in some sense the work which this war was intended to emphasize. ${ }^{16}$

However, Wilson clearly dissented from Barclay's contention that the ineffectiveness of pre-war international law had mainly been the result of 'unreasonable' nations. For the originator of the League Covenant, the 'engineers' and 'architects' of that international law also deserved part of the blame. Wilson's conclusion was that the new international order would still need international lawyers, but that they would not any longer be its driving force:

International law has perhaps sometimes been a little too much thought out in the closet. International law has-may I say it without offense?-been handled too exclusively by lawyers. Lawyers like definite lines. They like systematic arrangements. They are uneasy if they depart from what was done yesterday. They dread experiments. They like charted seas, and if they have no chart, hardly venture to undertake the voyage. Now we must venture upon uncharted seas to some extent in the future. In the new League of Nations, we are starting out upon uncharted seas, and therefore, we must have, I will not say the audacity, but the steadiness of purpose which is necessary in such novel circumstances. ${ }^{17}$

Wilson's critique of the international legal profession was not limited to the stereotypical overcautiousness of lawyers. It had also a markedly social

16 'After-Dinner Remarks' (Paris, 9 May 1919) 58 Papers of Woodrow Wilson (1988) 598, 599.

17 ibid. 
component. In fact, by invoking the 'moral rectitude of mankind' as the ultimate foundation of international law, Wilson was openly challenging the IDI's ability to reflect the 'legal conscience of the civilized world'. This must have become suddenly very clear to his exclusive audience when, later in his speech, he specified that 'when I think of mankind, I must say that I do not always think of well-dressed persons. ${ }^{\text {' }}$

Although his words were hardly gracious toward his audience, Wilson would turn out to be right. In the post-Versailles world, the implementation of 'peace through law' would no longer be the exclusive province of a small community of diplomats and highly-trained legal experts. It would be a markedly more inclusive matter. Of course, diplomats and political decision-makers would still play a central role. But they would now do so partly in public, defusing urgent crises within the Council of the League of Nations or discussing more general issues within its Assembly. As for the professional international lawyers, the multiplication of international conventions, organizations, and dispute settlement bodies provided them with numerous new research topics and career opportunities. However, the stage would also increasingly open up to other actors. Journalists would cover each session of the Assembly of the League of Nations and comment on various provisions of the Peace Treaties. Humanitarian activists would try to lobby Assembly delegates for more effective international rules on the repression of the slave trade or trafficking in women or children. Members of the League Secretariat would comment on the answers to legal questionnaires provided by member states. Minorities would send petitions to the League Council. Non-European populations subject to League mandates would try to protest the violation of their rights before the Permanent Mandates Commission. At the International Labour Organization, worker delegates would participate in the negotiation of international conventions. Populations of disputed territories would determine their future in legally binding plebiscites. Allied creditors of pre-war debts would sue the Entente Powers before one of 36 Mixed Arbitral Tribunals. Small-town lawyers would learn to help working class communities sue their own state before localized international bodies.

Of course, with the benefit of hindsight, the lofty ideals invoked by Woodrow Wilson and others before, during, and after the Paris peace negotiations stand in stark contrast to the eventual fate of the world they were supposed to protect. Far from producing 'peace through law', they re-

18 ibid. On Wilson's conception of international law, see: Leonard V Smith, 'The Wilsonian challenge to international law' 13 JHIL (2011) 179-208. 
sulted in contradictions that would lead to its very opposite. By basing their peace on legal principles that they presented as universally binding, the Allies raised expectations of justice that they were unwilling to meet while simultaneously limiting their own ability to decisively overpower those they had vanquished. ${ }^{19}$ And yet, from the perspective of international dispute settlement, the extreme variety and innovativeness of procedural and substantial 'experiments' attempted as a result of the Treaty of Versailles and the other Paris peace treaties of 1919-1920 remain striking even today. Moreover, although they have largely disappeared from the collective memories of the profession, many of these 'experiments' have had a lasting impact on international law and international dispute settlement after the Second World War. How did the Paris peace treaties try to resolve war-related and future international disputes? What institutions and dispute settlement mechanisms did they create? How did these institutions and mechanism operate in practice? What is their relevance for contemporary international law? These are some of the questions that this book, based on a conference held at the Max Planck Institute Luxembourg for Procedural on 6-8 December 2017, will address.

\section{Peace Through Law?}

In Chapter 1, which is intended to serve both as a general opening and a caveat, Nathaniel Berman invites us to take a step back from the main theme of this book. In his view, describing the Versailles Treaty as an illustration of 'peace through law' constitutes 'a dramatic gesture, 'a surprise, a provocation, a defiance of conventional wisdom. If anything, the international legal system created by the Treaty of Versailles and the other postWWI peace treaties showed that the dialectic between peace and violence lies not exclusively between the national and the international, but is often internal to the international itself. Setting aside the effectiveness of the Versailles regime in achieving or developing international dispute settlement, Berman analyses the way in which this regime has constructed the very frame in which the drama of international law-with its characters, its disputes and the means devised to settle them-still unfolds today. In particular, despite a few subsequent additions, the dramatis personae of the international stage created at Versailles remains globally familiar to a contempo-

19 Marcus M Payk, Frieden durch Recht? Der Aufstieg des modernen Völkerrechts und der Friedensschluss nach dem Ersten Weltkrieg (De Gruyter Oldenbourg 2018) 658-659. 
rary public. While holding on to national states as the protagonists of the international stage, Versailles formally introduced many new characters to it, such as international organizations, peoples in search of self-determination, 'not-yet-able' peoples, 'advanced nations', inhabitants of internationalized territories, or members of national minorities.

Insofar as it limited the state's monopoly on the international scene, the Versailles dramatis personae could be seen as an attempt to end the 'anarchy of sovereignties' that had led to the outbreak of the First World War. However, to such an extent as its characters-although originally presented as complementary-were often limiting each other, competing with each other, or undermining each other, it also had a definitively agonistic dimension. This agonistic dimension was further exacerbated when actors assumed parodic versions of Versailles personae to better undermine the system. Such was the case when Fascist Italy tried to use its prestige as an 'advanced nation' to recast Ethiopia as a conglomerate of 'not-yet-able' peoples in order to invade it. More generally, apart from proving unable to resolve the antagonisms between its characters, Versailles failed to produce a dramatis personae that the majority of the world could identify with. As a matter of fact, by barring certain actors - such as peoples living under colonial rule but not under a League mandate-from the list of authorized personae, the Versailles Treaty tacitly condoned their oppression and provoked their resistance. In doing so, it contributed to undermine the new international order it had created. Far from resolving its internal dialectic between peace and violence, the present-day international order-which, despite several major changes, is in many ways the continuation of the one established at Versailles-has perpetuated it. In this sense, the fact that 'peace through law' remains a promise, an aspiration, and a belief shared by many 'internationalists' should not prevent them from questioning its inherent limitations.

\section{The Establishment of a New International Order of Peace}

By incorporating the Covenant of the League of Nations, the Paris peace treaties instituted a greatly enhanced and systematized version of the scattered 'peace through law' mechanisms that had existed prior to the First World War. Whereas these mechanisms had been generally limited to 'peace through arbitration', the Covenant adopted a broader approach. The main element of this approach may be summed up as 'peace through dispute settlement'. Pursuant to Articles $12-15$ of the Covenant, member states were no longer left alone with disputes that might lead them to wage 
war against each other, but had the obligation to submit these disputes either to arbitration or judicial settlement or to the multilateral forum of the League Council. As demonstrated by Thomas D Grant in Chapter 2, both forms of dispute settlement benefitted from the League's (theoretically) universal and (mostly) egalitarian character. True, as the product of a still largely Eurocentric international environment in which sovereign equality remained a matter of contestation, the League was far from perfect in both respects. While the League's openness was unprecedented for an international body, for non-Western states such as Afghanistan and Ethiopia joining the organization would turn out to be an uphill battle. Similarly, although the League placed its members on an equal footing where voting rights were concerned, it nevertheless granted certain privileges to the Allies and the powers that they decided to co-opt into the Council. However, despite these limited departures from the principle of sovereign equality, the League still institutionalized this principle and provided its less powerful members with multiple procedural avenues. Moreover, inequalities within the political dispute settlement organs of the League were not essential to the functioning of the legal procedures that were independent of the League itself. It might even be said that the existence of a certain degree of formal equality between League members contributed to a climate of congeniality that facilitated the recourse to international adjudication.

The procedural requirement imposed upon League members to prevent armed conflicts between them fell short of an outright prohibition of war as a means to settle disputes-the substantive obligation which, pursuant to Article 2(4) of the United Nations Charter, constitutes the foundation of the present-day international order. ${ }^{20}$ Partly because of that limitation, the League's dispute settlement system would prove unable to prevent or end wars of aggression such as Japan's attack on China in 1931 and Italy's invasion of Ethiopia in 1935. However, it did resolve other serious crises where pre-1914 international dispute settlement mechanisms had clearly failed. One such case is presented in Chapter 3 by Michael D Callahan. On 9 October 1934, King Alexander I of Yugoslavia and the French Foreign Minister Louis Barthou were assassinated in Marseille by a member of an antiYugoslav group based in Italy and trained in Hungary. The attack was clearly reminiscent of the one carried out on Archduke Franz Ferdinand of Austria and his wife Sophie a little more than twenty years earlier in Sarajevo,

20 Robert Kolb, 'De la S.D.N. à l'O.N.U. en matière de maintien de la paix' in Robert Kolb (ed) Commentaire sur le Pacte de la Société des Nations (Bruylant 2015) $1331,1334-1342$. 
which had led to the outbreak of the First World War. But this time, the League and its dispute settlement organs helped prevent the crisis from escalating into armed conflict. Eventually, discussions at the League would result into two conventions that, had they ever entered into force, would have constituted the first legal regime defining international terrorism and the organization of its repression.

Despite the League's primary focus on the settlement of disputes between member states that had already reached some degree of escalation, the Covenant's contribution to world peace was not limited to that aspect. By addressing the rights of minorities, as well as social, economic, and colonial issues, it also targeted the underlying causes of war. Granted, the Covenant did not acknowledge the relationship between these issues and the maintenance of international peace quite as clearly as Article 1 of the United Nations Charter, with its 'contextualized' definition of peace, would after the Second World War. ${ }^{21}$ However, far from assuming that the League minimalistically considered peace as the absence of war, contemporary literature and practice suggest that even the Covenant's provisions on 'technical' issues were understood as a vital contribution to its 'political' role of preserving international peace. ${ }^{22}$

The contribution to world peace of the League of Nations' mandates system, established by Article 22 of the Covenant, might not seem apparent at first. For the peoples subject to A, B, or C mandates, whom that provision defined as 'not yet able to stand by themselves under the strenuous conditions of the modern world', the concept of the 'sacred trust of civilization' was hardly evocative of a clean break with aggressive $19^{\text {th }}$ century imperialism and colonialism. And as Mamadou Hébié and Paula Baldini Miranda da Cruz remind us in Chapter 4, the whole mandates regime, in its formalization of Great Power interests and its great reliance on classical racial stereotypes, was essentially a slightly modernized and more institutionalized form of pre-war colonialism. And yet, by denying the great colonial powers the right to simply annex former German colonies and Ottoman provinces, the Paris peace treaties partly reflected President Wilson's commitment to the principle of non-annexation. By doing so, they effectively contributed to removing one of the main incentives for future wars of conquest and, eventually, to outlawing war itself. Similarly, the obliga-

21 ibid.

22 See, eg: Olof Hoijer, Le Pacte de la Société des Nations: Commentaire théorique et pratique (Spes 1926) 387-388; Jean Ray, Commentaire du Pacte de la Société des Nations selon la politique et la jurisprudence des organes de la Société (Sirey 1930) 661. 
tion to maintain an 'open door policy' in mandated territories towards other members of the League was also a way of reducing the economic benefits commonly associated with territorial ambitions (while giving industrial nations with no or few colonies, such as the United States, access to colonial markets). As for the peoples governed under this regime, their limited right to petition the Permanent Mandates Commission not only reflected their embryonic right to self-determination. It also institutionalized a form of international oversight that contributed to establishing the way populations were treated as a matter of international concern and, therefore, as one of the foundations of international peace.

León Castellanos-Jankiewicz's contribution on minority rights in Chapter 5 offers a similarly contradictory image. During the $19^{\text {th }}$ century, the Great Powers, as part of the Concert of Europe, had regularly used minority rights to further their individual interests. The institution of a supervisory mechanism before the League Council as part of the different minorities treaties concluded during the Paris peace conference was clearly intended as a way to prevent such unilateral interference. Moreover, by conferring individual rights upon minorities, the minorities treaties were meant to strike a balance between assimilation and group protection. However, by prohibiting minorities from having direct recourse to the League Council, the minorities treaties pushed them toward seeking the intercession of their 'kin-states' and acting — or appearing to act—disloyally toward their territorial state. Another major flaw of the minorities treaties was their selectiveness: just as the peacemakers had alienated Japan by rejecting its racial equality clause, they alienated many Central European states by failing to impose minority protection obligations on Germany, let alone on themselves.

\section{The Emergence of International Economic Law}

The League of Nations was not the only international organization established in 1919-1920 with the intent to guarantee international peace. Expressly noting that '[universal] peace can be established only if it is based upon social justice, the Paris peace treaties also created an International Labour Organization (ILO). Not unlike the League Covenant, the ILO's Constitution was directly incorporated into each individual peace treaty. It eventually formed Part XIII of the Treaties of Versailles, Saint-Germain, and Trianon, and Part XII of the Treaties of Neuilly and Sèvres. In Chapter 6, Guy Fiti Sinclair examines the role of the ILO within the post-war settlement and the interwar period, and assesses its impact on post-WWII inter- 
national organization. Against the backdrop of wide-spread social unrest in many parts of the world and a successful revolution in Russia, the ILO's avowed objective was to turn away the workers from revolution, which the Preamble of its Constitution obliquely described as 'unrest so great that the peace and harmony of the world are imperilled. Instead, the creators and officials of the ILO advocated liberal reformism within the capitalist system. In this context, they heavily relied on law as a technology of liberal government par excellence. However, rather than putting the emphasis on hard norms of labour law, they were mostly concerned with institutional structures and procedures. One of their most remarkable achievements in this regard was the ILO's tripartite structure, which brought together groups with conflicting interests-governments, employers, and workers representatives - to resolve differences and adopt standard-setting conventions and recommendations by a majority vote. Moreover, with the ILO's growing expert and legal authority, it would also be increasingly concerned with economic issues, especially in the aftermath of the Great Depression.

While the drafters of the Versailles Treaty devoted considerable attention to universal labour issues, they refrained from adopting similarly far-reaching and detailed provisions with respect to international trade and finance. Article 23(e) Versailles Treaty merely comprised the broad commitment 'to secure and maintain freedom of communications and of transit and equitable treatment for the commerce of all Members of the League. However, in combination with Article 24, which stated that 'international bureaux and all commissions for the regulation of matters of international interest hereafter constituted shall be placed under the direction of the League', this provision would allow the League to become a major actor in the economic reconstruction of Europe. ${ }^{23}$ These provisions would also have a major impact on private international law and on commercial arbitration.

As explained by Herbert Kronke in Chapter 7, Article 24 Treaty of Versailles served as the legal basis for the creation of the International Institute for the Unification of Private Law (Institut International pour l'Unification du Droit Privé, UNIDROIT). Established in 1926 as an auxiliary organ of the League of Nations, UNIDROIT had the mission to harmonize and coordinate domestic legislations in the field of private law, with the aim of fostering mutually beneficial commercial exchange. Like other auxiliary

23 Throughout the 1920 s and 1930s, the League would progressively develop its agency in economic and financial affairs, eventually laying the groundwork for post-WWII international economic organization: Patricia Clavin, Securing the World Economy: The Reinvention of the League of Nations, 1920-1946 (OUP 2013) 10-12. 
organs or the League, UNIDROIT made an extensive use of independent experts, such as Antonio Scialoja, Ernst Rabel, and René David. Many of the legal creations of these experts are still of relevance today. For instance, although Rabel had to abandon his work on the harmonization of the law of the international sale of goods after his forced exile to the United States in 1939, it would have a major influence on the two Hague Conventions of 1964. However, UNIDROIT was not the only organization during the interwar period that claimed to promote peace through trade: in particular, the International Chamber of Commerce produced the 1923 and 1927 Geneva instruments on commercial arbitration that would in part inspire the 1958 New York Convention.

The sparseness of universal economic provisions in the Treaty of Versailles lies in stark contrast to its detailed regulations on German war reparations, of which two separate aspects are addressed here. In Chapter 8 , Jean-Louis Halpérin describes the creation and functioning of the Reparations Commission, a dispute settlement mechanism established pursuant to Article 233. Its mission was to define the amount of the damage for which Germany had to pay reparations pursuant to Articles 231-232, to draw up a schedule of payments, then to modify it according to the evolution of German resources. It also provided the German government the opportunity to have its interests heard. Between 1920 and 1923, in order to assert its authority, the Reparations Commission tried to present itself as an independent quasi-judicial body. However, due to its composition-its members were Allied politicians and diplomats-and its procedural practice-its proceedings were held in private and were not subject to any particular predetermined rules-it could hardly qualify as such. Already bypassed by government conferences and bilateral agreements, the Reparations Commission was soon plagued by deadlock as a result of disagreements among the Allies, before being disbanded in 1930 as a result of the Young Plan. A full account of how German reparations evolved into sovereign debt between the entry into force of the Versailles Treaty in 1920 and the final German payment-made in 2010-is given by Pierre d'Argent in Chapter 9. It shows how moral principles turned into overly rigid legal rules-with its 'war guilt clause' in Article 231, the Versailles Treaty can be described as a reversion to the idea of a 'just peace', which European nations had abandoned since the $16^{\text {th }}$ century ${ }^{24}$-were gradually replaced

24 Randall Lesaffer, 'Peace Treaties and the Formation of International Law' in Bardo Fassbender and Anne Peters (eds), The Oxford Handbook of the History of International Law (OUP 2012) 71, 88-91. 
by pragmatic financial arrangements. While underlining the potentially catastrophic consequences of naive legal expectations, this evolution also provides an additional illustration of the increasing influence that economists would acquire over political decision-makers during the interwar period and beyond.

\section{The Institutionalization of International Adjudication}

The growing impact of economic expertise on political decision-making during the interwar period did not coincide with a marginalization of international lawyers. Actually, by institutionalising international adjudication, the Treaty of Versailles and other international treaties created in its wake opened many new avenues for practitioners of international law.

Prior to the First World War, several attempts had already been made to create permanent international dispute settlement bodies that would be composed of sitting judges or arbitrators, rather than of adjudicators appointed by the parties for each individual case. Supporters of international judicial institutionalization hoped that permanent courts and tribunals would be able to develop a more consistent case law, thus contributing to the further development of international law. However, institutionalization during this period remained hesitant at best. Although the 1899 Hague Peace Conference resulted in the creation of the Permanent Court of Arbitration, this institution merely provided a more stable framework for individual disputes decided on an ad-hoc basis by party-appointed arbitrators. For the proponents of international judicial institutionalization, the outcome of the 1907 Hague Peace Conference was even more disappointing: rejecting the United States' proposal to create a Court of Arbitral Justice, the participating states approved the Convention Relative to the Creation of an International Prize Court only to see this project founder after the British Parliament failed to ratify it. ${ }^{25}$ The only fully institutionalized international court of the period, the Central American Court of Justice, had many limitations. For example, although individuals could file complaints before it, it only had jurisdiction over the five Central American republics

25 Cornelis G Roelofsen, 'International Arbitration and Courts' in Bardo Fassbender and Anne Peters (eds), The Oxford Handbook of the History of International Law (OUP 2012) 145, 165-166. 
(Costa Rica, Guatemala, Honduras, Nicaragua, and Salvador) and was not able to rule on more than 10 cases during its short existence (1907-1918). ${ }^{26}$

With these precedents in mind, the establishment of the Permanent Court of International Justice (PCIJ) pursuant to Article 14 Versailles Treaty in 1922 must be considered one of the most substantial and lasting contributions of that treaty to the materialization of 'peace through law' However, as Christian J Tams explains in Chapter 10, with its optional rather than compulsory jurisdiction, the PCIJ was a markedly less ambitious project than its abortive predecessors from the pre-war period. Moreover, its integration into the larger framework of the League of Nations also implied a more modest conception of 'peace through law. While states were ready to submit certain disputes to international adjudication, they were definitely not ready to renounce traditional 'political' means of dispute settlement, such as bi- and multilateral negotiations. In practice, this resulted in a level of judicial activity in the PCIJ that may be described as limited, but regular. While the Court was rarely handed over the most serious disputes, it made itself a solid reputation by solving smaller and midlevel conflicts, as well as by giving legal advice to international organizations. Moreover, the PCIJ effectively realized at least one of the hopes that many international lawyers had placed in the idea of institutionalized international adjudication: by systematically publishing its decisions and advisory opinions, the PCIJ produced a consistent body of case law that effectively contributed to the development of international law.

Today, the PCIJ remains the most prominent example of international judicial institutionalization after the First World War. However, the interwar period provides us with other compelling illustrations of this phenomenon. The Mixed Arbitral Tribunals (MATs), analysed in Chapter 11 by Marta Requejo Isidro and Burkhard Hess, are a case in point. Pursuant to Article 304 Versailles Treaty and similar provisions in the other postWWI peace treaties, their mission was to adjudicate various disputes regarding the treatment of private rights. This included settling monetary claims arising out of pre-war contracts and awarding compensation to Allied nationals for wartime measures taken against their property by the Central Powers' domestic courts. Numerically speaking, the 36 MATs-especially those between Germany and the Allied and Associated Powerswere undoubtedly the busiest international courts of the interwar period. Taken together, they decided on more than 70,000 cases. This caseload is

26 Rosa Riquelme Cortado, 'Central American Court of Justice' in Rüdiger Wolfrum (ed), Max Planck Encyclopedia of Public International Law (OUP 2013). 
even more impressive if one considers that their existence generally did not exceed 10 years, as most of the MATs were discontinued pursuant to the 1930 Young Plan. The MATs are similarly remarkable from a procedural point of view. First and foremost, their respective rules of procedure-several models were used due to the differences in legal traditions among the Allies - were so detailed that contemporaries described them as 'miniature civil procedure codes'. Another major innovation was the position of individuals before the MATs. Despite having to deal with mass claims, and although technically the right to submit and waive claims had been left to the states parties, the MATs nevertheless allowed the individuals whose rights were at stake to become directly involved in the proceedings. Due to their sheer number and the diversity of both the procedural and substantial rules that they applied, the MATs eventually failed to produce a universally consistent body of case-law. Nevertheless, their collection of published decisions was a major source for legal doctrine in the 1920s and 1930s and remains of interest for international lawyers today. In addition, although many accounts of the post-WWII era fail to mention the MATs, it should be noted that they served as a source of inspiration for the creators of the ECJ and might similarly inspire potential future negotiations over institutionalized investment tribunals.

Based on the model of the MATs but endowed with broader jurisdiction and an even wider range of procedural tools, the Arbitral Tribunal for Upper Silesia, which I describe in Chapter 12, is another example of international judicial institutionalization. Despite having been all but forgotten by international legal scholars and practitioners, it stands out as perhaps the most innovative international judicial body of its time. Its creation was the indirect result of Article 88 Versailles Treaty which provided for the division of Upper Silesia, one of Europe's major industrial regions, between Germany and the newly reborn Polish State. The partition of the ethnically mixed Upper Silesia was eventually implemented via the German-Polish Convention of 15 May 1922 - an intricate legal system that was at least partly the brainchild of the League of Nation's first Deputy Secretary-General, Jean Monnet. Although its duration had been limited to 15 years, the Convention established several major innovations. Most notably, it created two local, yet international, organs to ensure its effective implementation: the Mixed Commission for Upper Silesia and the Arbitral Tribunal for Upper Silesia. While the Mixed Commission has left an important mark in the field of minority rights, even bringing the Nazi authorities to temporarily suspend anti-Jewish legislation in German Upper Silesia between 1934 and 1937, the Arbitral Tribunal, which could publish generally binding decisions on complaints filed by individuals against their own state 
and receive preliminary referrals from national judges, might have served as an inspiration for both the ECtHR and the ECJ.

\section{Beyond 'Peace Through Law': The Use of Law and Its Records as Vehicles of Resistance and Change}

The League of Nations and the international adjudicatory bodies created as a result of the 1919-1920 Paris peace treaties introduced new mechanisms for the resolution of international disputes and provided effective international guarantees for certain individual rights. Yet, they ultimately failed to fulfill their assigned mission, namely 'to achieve international peace and security'. After the Second World War, political decision-makers and scholars were often keen to point out the insufficiencies of the 'peace through law' approach. For them, the drafters of the Versailles Treaty and the other Paris peace treaties had placed too much faith in legal principles and procedures instead of harnessing the military might of the world's great powers to organize their effective implementation. Therefore, the replacement of the League of Nations by the United Nations and its beefedup collective security system has been described as 'peace through law' making way for 'peace through power. ${ }^{27}$

To be sure, the post-WWII triumph of realism over legalism was far from absolute. In Europe, especially after the failure of the European Defence Community in 1954, regional integration has relied heavily on law and legal experts, and has further refined legal techniques that had already been experimented with by the League of Nations. On a global level, the considerable development of international adjudication after the end of the Cold War might be seen as a partial rehabilitation of post-WWI legalism and the ideal of 'peace through law'. However, as the current context makes clear once again, the multiplication of international legal rules and tribunals provides no ultimate guarantee against nationalism, unilateralism, and war. Nonetheless, as shown in the last part of this book, law itself also provides various means to overcome its inherent limitations as a peacemaker.

First, although law is predominantly associated with reconciliation and peace, it is also a formidable tool to organize public mobilization and resistance-including in times of war. As Dider Boden demonstrates in Chapter 13, even under occupation, judges are by no means bound to adopt a reconciliatory approach between the occupier and the occupied-although

27 Robert Kolb, Theory of International Law (Bloomsbury 2016) 387-388. 
historical precedents have shown that many are likely to do so under the circumstances. In 1915, rather than adding a veneer of legitimacy to certain German wartime impositions, two Belgian judges, Raymond de Ryckère and Maurice Benoidt, decided to use principles of international law-both public and private-to declare these measures illegal, thus openly questioning the occupier's authority. After initially rejecting this act of defiance, de Ryckère's and Benoidt's colleagues and superiors would eventually follow their lead, prompting a nation-wide strike of the judiciary that would leave the German occupier in awe and contribute to its eventual defeat.

Second, even when legal norms or proceedings fail to establish peace in the short term, the records they leave behind may be used as a later stage to foster mutual understanding and reconciliation between former enemies and, more generally, to contribute to societal change. The history of the Versailles Peace Treaty and the other post-WWI peace treaties is riddled with failures, unfulfilled hopes, and silences. Prominent examples include their incapacity to achieve a lasting peace between Germany and its neighbours, to bring to justice those responsible for the Armenian genocide, or to establish a principle of racial non-discrimination. In Chapter 14, Jennifer Balint, Neal Haslem and Kirsten Haydon argue that law, despite its silences and failures, can nevertheless effect societal change in the long run. For this to happen, the records that legal instruments and proceedings leave behind need to be 'translated' to the individuals and society to which they are directed. In their view, art is a potent vehicle to achieve this because it creates personal spaces within public spaces. These personal spaces facilitate engagement with, and recognition of, the meaning of law and its failures, as demonstrated by two art projects realized in Australia. The first of these projects, Minutes of Evidence, combines archival records and theatrical performance to address the unequal relations between Aboriginal residents and European settlers. The second project, Flowers of War, combines historical objects and visual arts to convey the enormity of war to a public that has never been confronted with it. Similar initiatives, based on international court proceedings, petitions filed before the League of $\mathrm{Na}$ tions, or archival records of the interwar period, might perhaps one day address the various instances in which the Paris peace treaties eventually failed to establish peace through law. 